\title{
VARIANSI ANGGARAN DAN REALISASI ANGGARAN BELANJA STUDI KASUS PEMERINTAH DAERAH PROVINSI DKI JAKARTA*)
}

\author{
Haryo Kuncoro* \\ Fakultas Ekonomi Universitas Negeri Jakarta
}

\begin{abstract}
The variance of spending is a common figure in any public sectors or even private sectors. In one hand, budget is a statement of performance estimation to be achieved in term of money. On the other hand, the budget realization is an actual achievement report. They could be different from each other because of the pragmatic changes in many factors. Consequently, the difference of those magnitutes indicates asymmetric information. This paper aims at analyzing the variance of expenditure in the case of Jakarta province over the period of 2004-07. Based on the statistical analysis, we conclude that the comparative theory did not hold. As the richest country in Indonesia, Jakarta tended to set spending budget (direct and indirect expenditures) differently across semester. When we investigate across both period and expenditure items, Jakarta did tend to set spending overestimate budget. In short, there were significant budgetary slacks. Those findings above could be associated with the classical problem in coordination of functions, programs, and activities.
\end{abstract}

Keywords: Variansi Anggaran, Belanja Langsung dan Tidak Langsung, Teori Komparatif, Asimetri Informasi

\section{Pendahuluan}

Anggaran pada dasarnya merupakan pernyataan mengenai estimasi kinerja yang hendak dicapai selama periode waktu tertentu yang dinyatakan dalam ukuran finansial. Lingkup sektor publik di Indonesia mengenal Rancangan Anggaran Pendapatan dan Belanja Negara (RAPBN) di tingkat pusat maupun RAPBD di tingkat daerah. Pada pasal 1 UU 17 tahun 2003 tentang Keuangan Negara, APBD diartikan sebagai rencana keuangan tahunan pemerintahan daerah yang disetujui oleh Dewan Perwakilan Rakyat Daerah (DPRD). Rancangan tersebut memuat pos-pos pendapatan dan belanja yang menjadi sasaran atau target yang hendak dicapai selama satu tahun.

Laporan Realisasi Anggaran merupakan bagian dari Laporan Keuangan Pemerintah Daerah seperti yang disyaratkan dalam Peraturan Pemerintah Nomor 24 tahun 2005 tentang Standard Akuntansi Pemerintah. Secara operasional, Menteri Dalam Negeri telah menindaklanjutinya dengan mengeluarkan Kepmendagri Nomor 13 tahun 2005 tentang Pedoman Pengelolaan Keuangan Daerah sehingga setiap Satuan Kerja Perangkat Daerah (SKPD) dapat meningkatkan kualitas pengelolaan dan transparansi laporan keuangan.

*) Paper ini dikembangkan dari laporan penelitian Analisis \& Evaluasi APBD DKI Jakarta 2004-2007, kerja sama antara Pemerintah Daerah Provinsi DKI Jakarta dengan Fakultas Ekonomi UNJ. Penulis menyampaikan penghargaan kepada semua pihak yang terlibat hingga terlaksananya penelitian ini. Terima kasih secara khusus ditujukan kepada Rida Prihatni dan Tresno Eka Jaya atas bantuan teknisnya. Isi tulisan ini merupakan pandangan pribadi sehingga kesalahan sepenuhnya bersumber dari (dan menjadi tanggung jawab) penulis. 
Penyusunan anggaran di publik merupakan suatu proses yang cukup rumit. Hal tersebut berbeda dengan penganggaran pada sektor privat. Anggaran pada sektor privat merupakan bagian dari rahasia perusahaan yang tertutup untuk publik. Sebaliknya pada sektor publik, anggaran justru harus diinformasikan kepada publik untuk dikritik dan didiskusikan untuk mendapat masukan. Anggaran sektor publik merupakan instrumen akuntabilitas atas pengelolaan dana publik dan pelaksanaan program-program yang dibiayai dari uang publik (Mardiasmo, 2005).

Dalam pelaksanaannya, perubahan-perubahan atas rencana anggaran yang telah ditetapkan sebelumnya lazim dilakukan. Praktik yang berlaku adalah Anggaran Murni dan Anggaran Perubahan. Anggaran murni adalah anggaran awal seperti termaktub dalam RAPBD. Anggaran Perubahan adalah anggaran yang ditetapkan setelah RAPBD berjalan. Selisih besaran antara realisasi dengan anggaran yang ditetapkan ini menjadi perhatian utama. Besaran angka tersebut secara tidak langsung mengungkapkan kapasitas SKPD dalam penyusunan anggaran.

Secara teknis, perkiraan keadaan yang akan terjadi di masa mendatang menjadi pertimbangan penting dalam penyusunan anggaran. Keadaan internal yang berada di bawah kendali semestinya bisa diakomodasikan dengan baik. Persoalan yang muncul adalah perubahan-perubahan eksternal yang berada di luar kendali sehingga sulit diperkirakan. Kemampuan melihat jauh ke depan semacam ini yang akan menentukan ketepatan anggaran dengan realisasinya. Selisih antara anggaran dengan realisasinya menjadi indikator "keberhasilan" penyusunan anggaran. Sebagai konsekuensinya, penyusun cenderung selalu bersikap mencari aman dengan menetapkan anggaran pada angka yang relatif rendah dengan harapan agar dapat dengan mudah dicapai realisasinya.

Dalam pemahaman akuntansi, masalah selisih anggaran ini erat berkaitan dengan besaran kandungan informasi laporan keuangan. Besaran (kebergunaan) kandungan informasi dapat diketahui dengan mengamati apakah informasi akuntansi memiliki kandungan informasi. Kandungan informasi tersebut sekaligus menunjukkan keberlakuan teori komparatif. Teori komparatif menyatakan bahwa daerah yang miskin cenderung untuk menetapkan anggaran pendapatan yang terlalu tinggi (overestimate revenue) dibandingkan dengan daerah yang relatif lebih kaya (Halim, 2002). Sebaliknya, anggaran belanja ditetapkan terlalu rendah (underestimate spending).

Dari aspek teori keagenan, pemunculan selisih anggaran sekaligus menunjukkan terjadinya asimetri informasi pada laporan keuangan tersebut. Pihak pemerintah daerah (sebagai agen) memiliki informasi lebih (berupa perubahan-perubahan yang terjadi) atas anggaran dan laporan keuangannya. Masyarakat umum (sebagai prinsipal), di sisi lain, hanya memiliki informasi atas laporan keuangan sebagaimana yang terpublikasi sungguhpun laporan anggaran perubahan telah diumumkan pula. Pihak yang berlebih informasi dapat meraih keuntungan atas kekurangtahuan pihak lain sehingga ia memiliki dis-insentif untuk mengungkapkan kelebihan informasinya. Kesemuanya ini membawa konsekuensi pada ketidakefisienan bagi semua pihak (Stiglitz, 1988).

Solusi yang ditawarkan untuk mengurangi ketidakseimbangan informasi tersebut diawali dengan mengukur perbandingan antara yang akan dituju (anggaran) dengan yang telah dicapai (laporan perhitungan anggaran). Paper ini berupaya mengamati variansi besaran 
selisih anggaran belanja dengan realisasinya. Untuk sampai kepada target tersebut, penulisan paper ini akan dimulai dengan tinjauan literatur. Studi empirik yang pernah dilakukan sebelumnya disajikan pada bagian berikutnya. Bagian keempat menjelaskan metode analisis dan data. Hasil analisis ditampilkan setelahnya. Akhirnya paper ini ditutup dengan beberapa catatan akhir.

\section{Landasan Teori}

Masalah insentif (incentive problem) dan informasi asimetri di sektor publik telah lama diidentifikasi oleh para ekonom. Dua pihak yang bersinggungan adalah birokrat dan masyarakat umum. Teori paling awal mengenai hal ini dikembangkan dalam kerangka kerja model Niskanen (1968). Menurut Niskanen, seseorang ketika belum terpilih menjadi birokrat akan berupaya untuk memaksimumkan fungsi kesejahteraannya sebagai anggota masyarakat. Namun, ketika ia sudah terpilih menjadi birokrat, preferensinya menjadi berbeda. Fungsi kesejahteraan birokrat bergantung pada seperangkat variabel, seperti gaji, keuntungan dan manfaat atas posisi politik yang spesifik diembannya, reputasi, dan kekuasaan. Kesemua faktor ini adalah dependen pada besarnya anggaran pemerintah.

Lebih lanjut, dalam pandangan Niskanen, pihak yang lebih kuat (decisive) dalam anggaran daerah bukannya masyarakat melainkan birokrat. Niskanen mengasumsikan bahwa para birokrat berperilaku memaksimisasi anggaran (budget maximization) sebagai proksi atas kekuasaannya. Model birokratik ini menegaskan bahwa selisih anggaran sebagai hasil dari perilaku birokrat (atau politisi lokal) dalam memaksimisasi anggaran yang lebih leluasa menggunakan anggaran. McGuire (1973) mengistilahkan perilaku tersebut sebagai model ketamakan para politisi lokal (a greedy politician's model). Grossman (1989; 1990) melukiskannya sebagai perilaku para politisi lokal dengan cakrawala pandang yang menyempit (myopic behavior).

Argumen di atas merupakan tahapan model birokratik yang paling sederhana dalam menjelaskan selisih anggaran. Dalam literatur Ekonomi Publik Lokal ada sejumlah penjelasan lain yang dikembangkan dari model birokratik ini. Romer dan Rosenthal (1979a), misalnya, menyatakan bahwa perbedaan anggaran daerah merupakan akibat dari ketidakseimbangan kekuatan antara masyarakat dengan birokrat daerah dalam pengambilan keputusan-keputusan publik. Romer dan Rosenthal mengistilahkan hal ini sebagai "tingkat pembalikan" (reversion leve).

Model di atas didasarkan pada pemungutan suara langsung terhadap pengeluaran pemerintah akan barang dan jasa publik tertentu. Menurut Romer dan Rosenthal (1979a), dengan superioritas informasi yang dimiliki, birokrat pemerintah daerah akan mampu mempengaruhi suara mayoritas hasil akhir dari pengambilan keputusan-keputusan publik melalui agenda kontrol. Lebih lanjut, Romer dan Rosenthal (1979b, 1980) dengan tajam menunjukkan bahwa apabila agenda anggaran publik telah didominasi oleh agen-agen politik maka hasil (outcome) dari anggaran pengeluaran tersebut akan ditentukan dengan taktik ancaman (threat).

Dougan dan Kenyon (1988) menolak pendapat bahwa efek stimulatif yang mengakibatkan selisih anggaran merupakan hasil lobi atas tekanan kelompok-kelompok politik lokal. Menurut Dougan dan Kenyon, kondisi sebagaimana yang dimaksud oleh Romer dan Rosenthal 
(1979b, 1980) tersebut lebih merefleksikan perubahan relatif posisi kesejahteraan (welfare) dari berbagai kelompok yang berkepentingan. Dalam hal ini, Romer dan Rosenthal serta Dougan dan Kenyon tampaknya hendak menggunakan pendekatan institusi politik yang berkembang di masyarakat dalam menjelaskan proses terjadinya selisih anggaran.

Masuknya faktor institusi politik ke dalam analisis di atas memang memberikan nuansa tersendiri. Meskipunpun demikian, analisis dengan memasukkan pendekatan institusi politik, dalam praktiknya, sulit dimodelkan secara empirik. Dalam hubungan ini, Holtz-Eakin (1992) mengembangkan model analisis yang mampu meliput perilaku politisi (yang terpilih dalam pemilihan umum) dalam menghadapi ketidakpastian. Politisi di daerah diasumsikan tetap akan memaksimumkan kekuasannya melalui penyusunan agenda anggaran yang mampu memaksimumkan utilitas pemilihnya.

Dalam analisis Holtz-Eakin masyarakat (konstituen) akan membandingkan antara paket kombinasi pajak dan pengeluaran yang ideal dengan paket yang disediakan oleh politisi pilihannya. Ketika perbedaan antara keduanya berada di bawah level tertentu yang dapat ditoleransi, masyarakat akan mengalihkan suaranya pada kandidat politisi yang lain. Situasi ini identik dengan "tingkat pembalikan" seperti yang dimaksudkan oleh Romer dan Rosenthal (1979a). Ketidakpastian dalam memperoleh dukungan suara inilah yang menyebabkan politisi yang sedang berkuasa cenderung untuk meningkatkan anggarannya (Duncombe, 1996).

Oates (dalam King, 1984) menyatakan bahwa fenomena selisih anggaran dapat dijelaskan dengan ilusi fiskal. Bagi Oates, selisih anggaran merupakan akibat dari ketidaktahuan masyarakat mengenai anggaran itu sendiri. Dalam cakupan yang lebih besar, ilusi fiskal -sebuah konsep yang diperkenalkan oleh Puviani pada awal tahun 1903 -- dapat diartikan sebagai kesalahan persepsi masyarakat baik mengenai aspek pembiayaan maupun pengalokasian anggaran. Ironisnya, keputusan mengenai aspek pembiayaan dan pengalokasian anggaran tersebut dihasilkan justru dari kesalahan persepsi semacam ini (Schawallie, 1989).

Dalam perkembangannya, penjelasan model ilusi fiskal ini terus berlanjut ke dalam berbagai variasinya. Dalam pemahaman yang lebih luas, ilusi fiskal dimengerti sebagai ketidaktahuan masyarakat atas beroperasinya sektor publik (Turnbull, 1993). Fenomena ilusi fiskal juga dapat dipandang sebagai sebuah elemen dari teori yang lebih luas, yaitu teori yang memasukkan pilihan (choice) individu yang ditransformasikan menjadi keputusan kolektif (Heyndels dan Smolders, 1994). Pilihan individu secara kolektif termanifestasi dalam pengeluaran pemerintah untuk penyediaan barang yang bersifat kolektif (barang dan jasa publik lokal) dan biaya kolektif dari penyediaan barang dan jasa publik lokal tersebut adalah tarif pajak. Oleh karena itu, ilusi fiskal dapat terjadi dan bersumber dari kompleksitas informasi atas kedua unsur tersebut.

Variasi ilusi fiskal yang pertama berasal dari distorsi pada sisi pengeluaran yang berakar dari ketidakseimbangan informasi antara kebijakan pengeluaran dengan kenaikan pajak yang otomatis. Pemikiran ini diajukan pada awalnya oleh Buchanan (1967). Menurut Buchanan, apabila perubahan sistem penerimaan diketahui (langsung atau tidak langsung) oleh masyarakat maka kenaikan pajak merupakan konsekuensi otomatis terhadap kegiatan perekonomian. Kenaikan pajak ini selanjutnya akan menciptakan "seretan fiskal" (fiscal drag) 
sehingga sistem fiskal akan sangat responsif terhadap tingkat inflasi yang pada akhirnya akan berakibat pada kecilnya selisih anggaran.

Dalam praktiknya, kenaikan beban pajak yang riil bagi masyarakat sangat ditentukan oleh sifat dan struktur pajaknya. Pembayar pajak bisa jadi mengalami kebingungan mengenai jumlah pajak yang harus dibayar jika struktur pajak sangat kompleks. Dengan demikian, sistem penerimaan pajak yang semakin sederhana diharapkan akan berjalan seiring dengan pengeluaran pemerintah yang semakin rendah. Proposisi ini dalam banyak literatur Ekonomi Publik disebut sebagai hipotesis kompleksitas penerimaan (revenue-complexity hypothesis) dan hipotesis elastisitas penerimaan (revenue-elasticity hypothesis). Oleh karena itu, hipotesis ilusi fiskal yang berkembang adalah bahwa upaya untuk menghilangkan distorsi tersebut akan menjadi determinan penting dalam menetukan besar-kecilnya selisih anggaran.

Variasi ilusi fiskal yang kedua berasal dari distorsi informasi pada sisi pengeluaran pemerintah daerah yang dalam banyak literatur Ekonomi Publik disebut sebagai hipotesis ilusi rente (renter illusion hypothesis) (Pommerehne dan Schneider, 1978; dan Vasquez, 1983). Misalkan ada kenaikan pajak daerah, katakan pajak kekayaan (property). Kenaikan pajak daerah ini akan menjadi tambahan beban penuh bagi pemiliknya. Bagi penyewa (renter) atas suatu kekayaan, kenaikan pajak tersebut bisa jadi bukan merupakan kenaikan beban yang senyatanya ia hadapi. Atas ketidakakuratan informasi mengenai kenaikan pajak yang senyatanya ia hadapi ini, para penyewa -- yang pada umumnya diasumsikan bukan sebagai penduduk setempat -- akan menuntut pengeluaran pemerintah setempat yang lebih tinggi sebagai imbalannya (Goetz, 1977). Dengan demikian, internalisasi dampak fiskal antardaerah semacam ini akan berbias pada realisasi kenaikan belanja pemerintah daerah.

Model birokratik dan ilusi fiskal pada prinsipnya menawarkan penjelasan mengenai sebab dan kronologi terjadinya selisih anggaran. Perbedaan yang paling mendasar antara model birokratik dan model ilusi fiskal adalah terletak pada sudut pandang analisisnya. Model birokratik, di satu sisi, menelaah terjadinya perbedaan anggaran dengan mengambil sudut pandang dari perilaku para birokrat di daerah, sedangkan model ilusi fiskal, di sisi yang lain, mendasarkan kajiannya dari sudut pandang perilaku masyarakat setempat dalam menyikapi keterbatasan informasi terhadap anggaran pemerintah daerah.

Riset tentang variansi anggaran dapat dikategorikan ke dalam dua kelompok besar. Kategori pertama berada pada area pemunculan variansi anggaran dengan titik berat pembahasan pada proses internal penganggarannya, seperti masalah partisipasi, kesenjangan anggaran, sistem, perilaku, dan kinerja. Beberapa penelitian anggaran di bidang sektor publik telah dilakukan antara lain oleh Johnson (1982) yang menggunakan pendekatan etnometodologi dalam penelitian perilaku anggaran. Gordon dan Sellers (1984) membuktikan bahwa sistem informasi akuntansi sejalan dengan sistem penganggaran organisasi.

Untuk kasus pemerintah daerah di Indonesia, Suryani (2004) menunjukkan bahwa filosofi budaya setempat sangat baik digunakan untuk pedoman penyusunan anggaran daerah di Sumba Timur. Munawar (2006) menunjukkan bahwa karakteristik tujuan anggaran berpengaruh secara signifikan terhadap perilaku dan sikap aparat daerah. Rahayu, Ludigdo, dan Affandy (2007) mengamati penyusunan anggaran pada salah satu SKPD di provinsi Jambi. Studi mereka bercirikan sangat fenomenologis dalam mengungkap berbagai hambatan dalam penyusunan anggaran dari beberapa aspek sehingga terjadi kesenjangan 
anggaran. Falikhatun (2007) menelaah kesenjangan anggaran di organisasi publik nir laba dari sisi partisipasi. la menyimpulkan variabel informasi asimetri dan kekompakan kolektif (group cohesiveness) merupakan variabel yang dapat memperkuat pengaruh partisipasi penganggaran terhadap kesenjangan anggaran (budgetary slack).

Secara umum, pendekatan yang digunakan oleh para peneliti di atas lebih bersifat kualitatif dengan cakupan yang lebih mikro bahkan studi kasus. Oleh karena itu, simpulan-simpulan yang dihasilkan kurang dapat digeneralisasikan. Di sisi lain, kelompok kedua memposisikan diri pada area variansi anggaran sebagai hasil sebagaimana yang terjadi. Kategori ini lebih sering menggunakan pendekatan positivisme. Analisis paham positivisme beranjak dari hasil baru kemudian mengkaji lebih jauh sebab-musababnya secara eksternal. Pendekatan yang digunakan oleh kelompok ini adalah lebih bersifat kuantitatif dengan cakupan yang lebih makro. Konsekuensinya, simpulan-simpulan yang dihasilkan lebih dapat digeneralisasikan.

Segaris dengan paham positivisme, kajian pada level pemerintah daerah di negara-negara maju telah dilakukan sebelumnya oleh beberapa peneliti, seperti Rubin (1987), Sutter dan Wilson (1990), Staple dan Rubin (1997), serta Dougherty et.al. (2000) (lihat Halim, 2001). Kajian mereka tentang selisih anggaran dikaitkan dengan fenomena ekonomi atau politik sebagai sumber terjadinya tekanan fiskal (fiscal stress). Hasil beberapa studi di atas menyimpulkan bahwa faktor eksternal yang berada di luar kendali pemerintah daerah sangat dominan dalam menentukan besaran selisih anggaran.

Untuk kasus di negara berkembang, analisis tentang anggaran pemerintah daerah dikaitkan dengan transfer karena lemahnya kondisi keuangan daerah. Slack dan Bird (1983), misalnya, memperoleh bukti adanya efek substitusi antara penerimaan transfer dengan penerimaan lokal di Kolumbia. Mereka menunjukkan bahwa pemerintah daerah membelanjakan anggaran dalam jumlah lebih sedikit daripada transfer yang didapatkan sehingga mengurangi penerimaan pajak lokal. Atas dasar ini, Slack dan Bird menyimpulkan kecilnya selisih anggaran, dalam arti pemerintah daerah menganggarkan pengeluaran yang lebih kecil daripada transfer yang diterima dan kemudian mengurangi penggunaan sumber keuangan lokal dalam membiayai anggaran pengeluarannya. Temuan ini selaras dengan hasil studi Gallagher (1999) untuk kasus El Salvador.

Untuk kasus di negara sedang berkembang lainnya, Naganathan dan Sivagnanam (1999) meneliti pengaruh transfer pada upaya pengumpulan pajak di daerah. Menurut Naganathan dan Sivagnanam, studi mengenai pengaruh transfer yang dilakukan di negara maju lebih berorientasi pada pengeluaran dan jarang yang memperhatikan pengaruhnya pada aspek penerimaan. Berdasarkan pengamatan atas data di India selama periode 196984, mereka menemukan bahwa aliran transfer yang telah direncanakan sebelumnya memberikan pengaruh negatif pada upaya pengumpulan pajak di tingkat lokal. Sebaliknya, aliran transfer yang tidak direncanakan sebelumnya memberikan pengaruh positif pada upaya pengumpulan pajak di tingkat lokal.

Kajian tentang selisih anggaran di Indonesia lebih banyak dihubungkan fenomena disparitas. Wuryanto (1996), misalnya, menelaah kondisi keuangan daerah pada pertengahan tahun 1980-an bersamaan dengan kebijakan penyesuaian struktural dan stabilisasi yang diimplementasikan pemerintah. Sejalan dengan langkah-langkah di atas, kebijakan dalam bidang anggaran ditempuh melalui pengurangan secara substansial ragam pengeluaran 
pemerintah pusat dan reformasi perpajakan. Wuryanto menyimpulkan pengurangan anggaran belanja pemerintah ternyata tidak diikuti dengan kebijakan ekonomi regional yang komprehensif sehingga semakin memperburuk disparitas antarwilayah antara pertengahan tahun 1980-an.

Terkait dengan aspek pertumbuhan ekonomi dan pemerataan pembangunan antardaerah ini, Majidi (1997) dan Nurmanaf (1999) menunjukkan perbedaan anggaran belanja daerah ini sejalan dengan sebaran PDRB. Lebih lanjut, perbedaan belanja dan PDRB terkait pula dengan konfigurasi perbedaan anggaran penerimaannya (Nazara, 1997). Studi-studi di atas memperlihatkan daerah yang lebih maju memiliki kemampuan lebih dalam meredam perubahan struktural yang terjadi atas anggaran penerimaan dan belanjanya sehingga selisih anggarannya tidak mengalami perubahan yang drastis.

Halim (2001) mengamati tekanan fiskal pemerintah daerah provinsi akibat pemberlakuan UU No. 18/1997 tentang pajak daerah dan retribusi daerah. Menurut Halim, UU tersebut membawa akibat pada labilnya sektor penerimaan daerah yang selanjutnya membawa konsekuensi rendahnya tingkat kepastian besarnya anggaran yang dapat dibelanjakan. Tingkat kepastian penerimaan yang rendah tersebut menyebabkan kemungkinan adanya pergeseran-pergeseran pada komponen pendapatan dan belanja akan menjadi lebih besar. Melalui pengujian statistika beda rerata antara titik waktu 1996/97 dengan 1998/99, Halim sampai pada simpulan bahwa pemberlakuan UU No. 18/1997 ini berpengaruh hanya pada penerimaan retribusi daerah (bukan pada penerimaan pajak daerah).

Halim (2002) lebih mendalam lagi mengkaji variansi PAD kota dan kabupaten di Indonesia. Fenomena perubahan struktural yang dimasukkan adalah krisis ekonomi 1997. Hasil temuannya adalah terjadi variansi anggaran yang besar atas PAD kota dan kabupaten antara sebelum dan sesudah krisis. Temuan menarik lainnya adalah terdapat hubungan negatif antara derajad otonomi daerah dengan besaran variansi anggaran terutama di Jawa-Bali dengan di luar Jawa-Bali. Sayangnya, Halim dalam analisisnya tidak menunjukkan apakah tekanan fiskal yang terjadi lebih disebabkan oleh pemberlakuan UU tersebut atau karena krisis ekonomi yang secara kebetulan bermula pada waktu yang bersamaan.

Kuncoro (2005) menelaah perbedaan pendapatan dan belanja pemerintah daerah kota dan kabupaten. la membedakan tidak hanya antara sebelum dan sesudah krisis tetapi juga antara periode sebelum dan sesudah otonomi daerah. Melalui estimasi persamaan sistem, ia menyimpulkan terjadi perubahan anggaran yang signifikan masing-masing pada kedua perbedaan spektrum waktu tersebut. Secara lebih spesifik, Kuncoro (2007) menyimpulkan perbedaan anggaran yang cukup besar bukan hanya penerimaan tetapi juga pada belanja, transfer, pertumbuhan ekonomi, dan ketimpangan pendapatan regional antarkota dan kabupaten.

Studi-studi di atas menunjukkan beberapa poin penting. Pertama, besaran variansi anggaran secara umum berasosiasi dengan kondisi-kondisi yang bersifat eksogen, seperti perubahan kondisi ekonomi, politik, dan kebijakan pemerintah pusat. Kedua, besaran variansi anggaran berbeda-beda tergantung pada kemampuan ekonomi daerah dalam merespon perubahan eksogen tesebut. Ketiga, besaran variansi anggaran sangat berkorelasi dengan kondisi kinerja keuangan pemerintah daerah. Beberapa poin di atas memberi inspirasi untuk melakukan sedikit inovasi. 
Studi ini berbeda dengan penelitian sebelumnya dalam beberapa hal. Pertama, kasus yang diambil adalah provinsi DKI Jakarta. Sebagai daerah terkaya di Indonesia, analisis variansi anggaran pemerintah daerah provinsi DKI akan menunjukkan keberlakuan teori komparatif secara lebih kentara. Kedua, rentang waktu yang diambil adalah periode 2004-2007. Periode ini dipilih sehubungkan dengan tidak adanya perubahan-perubahan yang bersifat struktural baik di bidang ekonomi maupun politik. Ketiga, variansi anggaran yang dianalisis mencakup data semesteran dan mengamati lebih jauh antarpos anggaran. Atas dasar ketiga hal tersebut, analisis variansi anggaran akan bisa lebih fokus kepada faktor-faktor internal.

\section{Metode Penelitian}

Paper ini lebih menempatkan diri pada aliran positivisme. Oleh karena itu, aspek-aspek lain yang berkaitan dengan masalah kebocoran belanja tidak dibahas dalam penelitian ini. Demikian pula, nuansa masalah efisiensi dan efektivitas belanja juga tidak dibicarakan sama sekali. Penjelasan di atas ditegaskan secara eksplisit untuk memperkuat basis analisis teori komparatif.

Metode analisis untuk mengamati besaran selisih anggaran belanja antarsemester adalah uji beda rerata. Uji ini merupakan perangkat statistika untuk pengujian hipotesis. Tujuan analisis uji beda rerata adalah untuk memeriksa adanya beda rerata dari dua kelompok populasi. Mengingat subjeknya tetap sama dengan beda hanya pada lintas semester, uji beda rerata yang sesuai adalah uji beda rerata berpasangan (a paired mean difference test).

Untuk bisa melakukan uji beda rerata berpasangan, masing-masing unsur populasi (dengan anggota sampel sebanyak $n=n_{1}=n_{2}$ ) dilakukan pengurangan. Hasil pengurangan ini kemudian dihitung reratanya $(\mu)$. Dengan sendirinya, deviasi standard $(\sigma)$ juga dapat diperoleh. Perhitungan teknis uji beda rerata berpasangan kemudian adalah

$t-$ hitung $=\frac{\mu}{[\sigma / \sqrt{n}]}$

Lebih lanjut, metode analisis untuk mengamati besaran selisih anggaran belanja lintas semester dan pos anggaran adalah analisis variansi (analysis of variance/Anova). Tujuan analisis variansi adalah untuk memeriksa adanya beda rerata dari tiga kelompok populasi atau lebih. Mengingat yang hendak dianalisis mengetengahkan dua faktor (lintas semester dan lintas pos anggaran), anova yang sesuai adalah anova dua jalur (two way anova).

Analisis variansi bertitik tolak dari variansi. Variansi merupakan perbedaan kuadrat antara semua nilai dengan reratanya. Variansi dapat berasal dari perbedaan atas rerata total dan atas rerata kolom (baris). Variansi yang disebut pertama disebut variansi total (SST, sum of square total). Variansi yang terakhir disebut adalah variansi kolom (SSC, sum of square column), serta variansi baris (SSR, sum of square row). Variansi total, SST, diperoleh dengan cara mengkuadratkan perbedaan setiap nilai terhadap rerata totalnya $\left(\mu_{\dagger}\right)$. 
SST $=\Sigma\left[\mathrm{X}_{i}-\mu_{\dagger}\right]^{2}$

Variansi kolom diperoleh dengan cara mengkuadratkan perbedaan setiap nilai di masingmasing kolom terhadap rerata di tiap kolom $\left(\mu_{k}\right)$. Logika yang sama bila diterapkan untuk baris didapatkan variansi baris (dengan rerata di tiap baris $\mu_{\mathrm{b}}$ ).

$\operatorname{SSC}=\Sigma\left[\mathrm{X}_{i}-\mu_{k}\right]^{2} ; \quad \operatorname{SSR}=\Sigma\left[\mathrm{x}_{i}-\mu_{b}\right]^{2}$

Variansi sisa yang tidak bisa dijelaskan (SSE, sum of square error) merupakan sisa dua variansi yang telah diperoleh sebelumnya.

SSE $=$ SST - SSC - SSR

Masing-masing nilai variansi masih harus dikoreksi dengan derajad kebebasan (degree of freedon, DF). Nilai SST dibagi dengan N-1, nilai SSC dikoreksi dengan C-1, SSR dibebani dengan R-1, dan nilai SSE disesuaikan dengan ((C-1)x(R-1)). Anova ditempuh dengan membandingkan antara variansi kolom dan variasi baris dengan variansi yang tidak terjelaskan:

$F-\operatorname{hitung}(1)=\frac{\operatorname{SSC} /(C-1)}{\operatorname{SSE} /[(C-1) x(R-1)]} ; \quad F-$ hitung $(2)=\frac{\operatorname{SSR} /(R-1)}{\operatorname{SSE} /[(C-1) \times(R-1)]}$

$\mathrm{N}=$ cacah data; $\mathrm{C}=$ cacah kolom; $\mathrm{R}=$ cacah baris

Kedua perangkat statistika di atas akan diterapkan pada data Laporan Perhitungan Anggaran semesteran selama periode 2004-07. Selama periode tersebut, Laporan Perhitungan Anggaran masing menggunakan format lama, yaitu mengikuti Kepmendagri No. 20 tahun 2002. Klasifikasi yang dianut adalah Belanja Aparatur dan Belanja Pelayanan Publik. Mengikuti pasal 36 Kepmendagri No. 13/2006, Klasifikasi yang dianut adalah belanja langsung dan belanja tidak langsung. Kelompok belanja tidak langsung merupakan belanja yang dianggarkan tidak terkait secara langsung dengan pelaksanaan program dan kegiatan. Kelompok belanja langsung merupakan belanja yang dianggarkan terkait secara langsung dengan pelaksanaan program dan kegiatan. Konversi ke dalam klasifikasi yang baru diringkas ke dalam Gambar 1.

Selisih perhitungan anggaran yang akan dikaji difokuskan pada pos-pos belanja langsung dan belanja tidak langsung. Pos belanja langsung terdiri dari 14 item dan belanja tidak langsung mencakup 75 item mata anggaran. Klasifikasi masing-masing jenis belanja dapat dilihat pada Tabel 1. Selisih anggaran belanja dinyatakan ke dalam bentuk relatif. Bentuk ini lebih realistik daripada bentuk absolut jika selisih anggaran yang hendak diperbandingkan adalah lintas pos-pos anggaran. Selisih anggaran dalam bentuk relatif dapat dinyatakan sebagai: 
Variansi $=\frac{\text { Realisasi }}{\text { Anggaran }} \times 100$

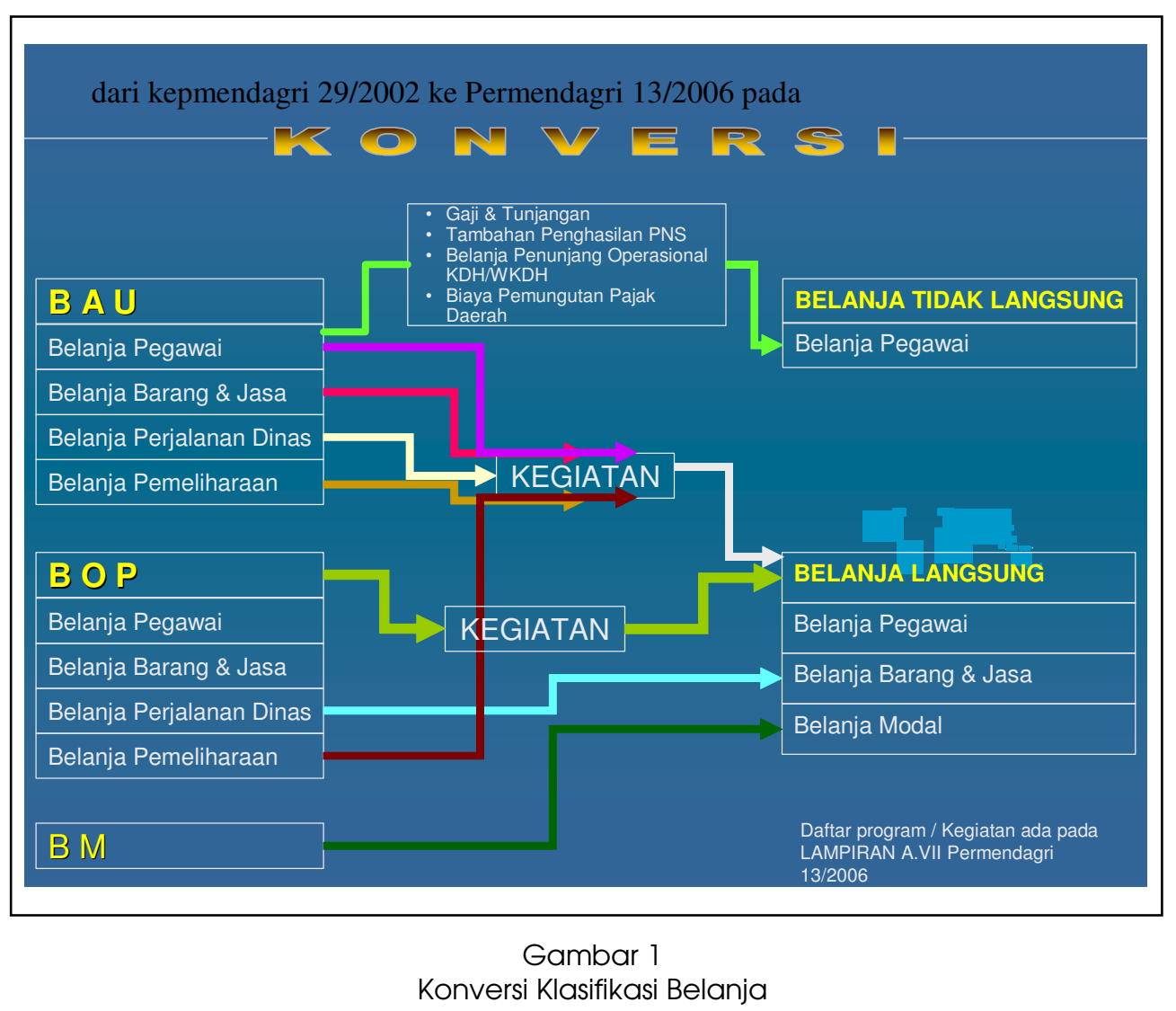

Atas dasar formula tersebut, ketepatan panganggaran ditunjukkan dengan skor variansi anggaran sebesar 100. Realisasi anggaran yang tidak tercapai ditunjukkan dengan skor variansi anggaran sebesar kurang dari 100. Realisasi yang melebihi anggaran dinyatakan dengan angka variansi sebesar lebih dari 100*. Atas dasar spesifikasi ini, pos belanja yang ada realisasinya tetapi tidak dianggarkan sebelumnya tidak diikutsertakan ke dalam analisis.

*) Formula perhitungan variansi anggaran ini berbeda dengan Halim (2002). Spesifikasi yang digunakan Halim adalah:

$$
\text { Variansi }=\frac{\text { Anggaran }- \text { Realisasi }}{\text { Anggaran }} \times 100
$$

Rumus ini memungkinkan variansi bertanda positif dan negatif. Cara ini kurang sesuai digunakan dalam uji beda rerata dan anova yang berbasis pada rerata hitung (arithmethic mean). 
Anggaran menggunakan dua konsep. Konsep pertama mengacu pada anggaran murni (definisi A). Konsep kedua merujuk pada anggaran perubahan (definisi B). Keseluruhan data mentah didapatkan dari Laporan Perhitungan Anggaran yang dikelola oleh Biro Keuangan Sekretariat Daerah Pemerintah Daerah Provinsi DKI Jakarta. Semua data telah terekam ke dalam format microsoft excel sehingga memudahkan pengolahan selanjutnya.

Tabel 1

Pos Belanja Langsung dan Belanja Tidak Langsung

\begin{tabular}{llll}
\hline \multicolumn{2}{c}{ Pos Belanja Langsung } & & \multicolumn{1}{c}{ Pos Belanja Tidak Langsung } \\
\hline 1 & Belanja Pegawai & 1 & Belanja Pegawai \\
2 & Belanja Barang dan Jasa & 2 & Belanja Bunga \\
3 & Belanja Modal & 3 & Belanja Subsidi \\
& 4 & Belanja Hibah \\
& 5 & Belanja Bantuan Sosial \\
& 6 & Belanja Bagi Hasil \\
& 7 & Belanja Bantuan Keuangan \\
& 8 & Belanja Tidak Terduga \\
\hline
\end{tabular}

Sumber: Lampiran A.VIII Permendagri No. 13/2006 tanggal 15 Mei 2006

Tinjauan Umum

Jakarta yang berperan sebagai ibukota negara diberi kedudukan khusus sebagai sebuah provinsi dengan nama Daerah Khusus Ibukota Jakarta. Sampai saat ini, provinsi ini masih memiliki wilayah kotamadya dan kabupaten yang bukan merupakan wilayah otonom. Otonomi hanya diberikan pada tingkat provinsi sehingga kotamadya dan kabupaten tersebut tidak mempunyai APBD sendiri melainkan tercakup ke dalam APBD provinsi.

Pada tingkat provinsi dibentuk DPRB sebagai badan legeslatif daerah dan Pemerintah Daerah sebagai badan eksekutif daerah. Pemerintah daerah terdiri atas Gubernur dan perangkat provinsi (sekretaris daerah, kepala dinas, walikota/bupati). Pada tingkat kota/kabupaten dibentuk dewan kota/kabupaten sebagai mitra kerja pemerintah kota/kabupaten. Anggota dewan kota/kabupaten dipilih oleh DPRD dari tokoh masyarakat yang diusulkan kelurahan.

Perannya sebagai pusat pemerintahan negara, industri, perdagangan, dan kelengkapan infrastrukturnya mempesona bagi aliran sumber daya modal, manusia, fisik, maupun finansial masuk ke kota ini. Proses urbanisasi total terjadi dan kemudian berimbas pada daerahdaerah di sekitarnya. Jumlah penduduk Jakarta mencapai 12 juta jiwa menjadikannya salah satu kota terpadat di Asia. Kesemuanya ini menjadikan kegiatan ekonomi di wilayah provinsi DKI Jakarta jauh meninggalkan kota-kota lain di Indonesia.

Dalam hal keuangan daerah, provinsi DKI Jakarta juga menunjukkan prestasinya. Provinsi ini merupakan daerah dengan volume APBD tertinggi atas semua provinsi di Indonesia. Capaian ini juga terjadi pada sisi belanjanya. Pada tahun 2004 total belanja pemerintah daerah provinsi DKI Jakarta tidak kurang dari 20 trilyun rupiah. Angka ini terus berkembang hingga mencapai 34 trilyun pada tahun 2007 atau mengalami pertumbuhan rerata sebesar 12 persen per tahun (lihat Tabel 2). 
Diperiksa lebih lanjut masih pada sisi belanjanya, pemerintah daerah provinsi DKI Jakarta juga mempunyai angka belanja langsung dan tidak langsung yang tertinggi di seluruh Indonesia. Selama periode yang sama, angka belanja langsung pemerintah daerah provinsi DKI Jakarta mencapai 12,5 trilyun rupiah (2004) hingga 20,7 trilyun rupiah (2007). Angka-angka tersebut mencapai hampir 60 persen atas total belanja APBD. Apabila proporsi mengindikasikan skala prioritas, hal ini berarti belanja langsung menjadi tumpuan pemerintah daerah dalam memfasilitasi pembangunan daerah.

Tabel 2

Struktur Belanja Pemerintah Daerah Provinsi DKI Jakarta, 2004-2007 (Juta Rupiah)

\begin{tabular}{clrrrr}
\hline Pos & Realisasi Anggaran & \multicolumn{1}{c}{2004} & \multicolumn{1}{c}{2005} & \multicolumn{1}{c}{2006} & \multicolumn{1}{c}{2007} \\
\hline A & Total Belanja & $20,926,390$ & $24.175,451$ & $28.796,316$ & $34.147,937$ \\
B & Belanja Langsung & $12.500,210$ & $14.569,869$ & $17.206,072$ & $20.732,153$ \\
& Proporsi thd A (\%) & 59,73 & 60,27 & 59,75 & 60.71 \\
C & Belanja Tidak Langsung & $8.426,179$ & $9.065,583$ & $11.590,243$ & $13.415,784$ \\
& Proporsi thd A (\%) & 40,27 & 39,73 & 40,25 & 39.28 \\
\hline
\end{tabular}

Sumber: Pemda Provinsi DKI Jakarta

Tabel 3 lebih jauh mendiskripsikan perbedaan antara realisasi dengan anggarannya. Mengikuti definisi A, selama tiga tahun terakhir rerata selisih anggaran belanja langsung memperlihatkan penurunan yang berarti. Secara umum, rerata selisih anggaran belanja langsung mencapai 107 persen. Artinya, dalam satu tahun secara umum anggaran yang ditetapkan dapat dicapai bahkan melebihi 7 persennya. Pola yang berbeda terjadi pada selisih anggaran penerimaan pajak daerah dengan definisi B khususnya pada tiga tahun terakhir. Mengikuti definisi B, secara keseluruhan belanja langsung relatif lebih sesuai dengan anggaran yang ditetapkan.

Tabel 3

Statistik Diskriptif Variansi Anggaran Belanja Langsung Pemerintah Daerah Provinsi DKI Jakarta, 2004-2007

\begin{tabular}{rlrrrr}
\hline Variansi Anggaran & Tahun & \multicolumn{1}{c}{2004} & \multicolumn{1}{c}{2005} & \multicolumn{1}{c}{2006} & \multicolumn{1}{c}{2007} \\
\hline Definisi A & Rerata & 102.21 & 113.76 & 112.05 & 103.45 \\
& Maks & 208.36 & 195.12 & 492.65 & 220.92 \\
& Min & 8.36 & 19.70 & 9.22 & 5.14 \\
& Median & 81.08 & 119.19 & 94.76 & 106.38 \\
& DS & 66.51 & 58.19 & 95.57 & 62.84 \\
Definisi B & Rerata & 97.57 & 113.14 & 96.91 & 103.45 \\
& Maks & 178.67 & 195.12 & 197.59 & 220.92 \\
& Min & 6.57 & 24.75 & 2.51 & 5.14 \\
& Median & 81.08 & 119.19 & 94.76 & 106.38 \\
& DS & 62.66 & 57.10 & 62.22 & 62.84 \\
\hline
\end{tabular}

Sumber: Pemda Provinsi DKI Jakarta

Selisih anggaran belanja terhadap anggaran perubahan tampak lebih kecil daripada selisih anggaran belanja terhadap anggaran murni. Menilik kembali pada definisi selisih anggaran, besaran variansi anggaran setelah ada perubahan anggaran tampak lebih kecil daripada variansi terhadap anggaran murni. Hasil ini secara intuisi masuk akal. Perubahan anggaran dilakukan pada saat RAPBD berjalan. Situasi dan kondisi yang berubah dapat 
diakomodasikan dengan baik sedemikian rupa sehingga sudah semestinya selisihnya menjadi semakin kecil.

Tabel 4 juga menyajikan statistik diskriptif selisih anggaran belanja tidak langsung. Rerata besaran selisih anggaran belanja tidak langsung juga menunjukkan kecenderungan turun. Dibandingkan dengan belanja langsung, besaran perbedaan antara anggaran belanja tidak langsung dengan realisasinya tampak lebih beragam. Hal ini diperlihatkan oleh simpangan baku dan juga oleh perbedaan antara nilai maksimum dan minimum yang lebih besar daripada belanja langsung. Dengan menggunakan ukuran koefisien variasi, simpulan bahwa angka rerata selisih anggaran belanja tidak langsung lebih mewakili daripada angka rerata selisih anggaran belanja langsung akan lebih jelas.

Tabel 4

Statistik Diskriptif Variansi Anggaran Belanja Tidak Langsung Pemerintah Daerah Provinsi DKI Jakarta, 2004-2007

\begin{tabular}{clrrrr}
\hline Variansi Anggaran & Tahun & \multicolumn{1}{c}{2004} & \multicolumn{1}{c}{2005} & \multicolumn{1}{c}{2006} & \multicolumn{1}{c}{2007} \\
\hline Definisi A & Rerata & 82.15 & 84.66 & 72.22 & 50.48 \\
& Maks & 210.84 & 906.05 & 182.93 & 190.26 \\
& Min & 0.80 & 2.05 & 0.53 & 0.56 \\
& Median & 82.14 & 70.51 & 58.29 & 26.94 \\
& DS & 68.70 & 88.51 & 53.77 & 53.91 \\
Definisi B & Rerata & 80.38 & 77.61 & 70.84 & 50.15 \\
& Maks & 199.24 & 183.85 & 182.93 & 190.26 \\
& Min & 0.79 & 0.89 & 0.30 & 0.33 \\
& Median & 79.18 & 77.76 & 59.20 & 26.76 \\
& DS & 66.99 & 54.61 & 52.77 & 53.88 \\
\hline
\end{tabular}

Sumber: Pemda Provinsi DKI Jakarta

Catatan: DS adalah deviasi standard

Sampai di sini, evaluasi sekilas atas Tabel 3 dan Tabel 4 mengarahkan intuisi kepada simpulan awal bahwa variabilitas selisih anggaran potensial terjadi pada besaran sisi belanja tidak langsung (relatif daripada besaran sisi belanja langsung). Apakah hal ini hanya terjadi secara kebetulan semata atau memang demikian adanya? Dua subbab berikut akan memastikannya dengan perangkat statistika inferensial.

Variansi Antarsemester

Tabel 5

Ringkasan Hasil Uji Beda Rerata Lintas Semester Variansi Belanja Langsung Pemerintah Daerah DKI Jakarta

\begin{tabular}{cccccc}
\hline Variansi & Nilai & \multicolumn{4}{c}{ Tahun } \\
\cline { 3 - 6 } Anggaran & Uji & 2004 & 2005 & 2006 & 2007 \\
\hline Definisi A & t-hitung & 16.9780 & 17.1740 & 4.4690 & 9.2727 \\
Definisi B & t-hitung & 22.8085 & 19.3746 & 12.4393 & 9.2727 \\
\hline
\end{tabular}

Nilai t-tabel $(5 \% ; 26)=2.379$ (satu sisi)

Sumber: Pemda Provinsi DKI Jakarta (diolah)

Tabel 5 menyajikan ringkasan hasil uji beda rerata lintas semester belanja langsung untuk setiap tahunnya. Nilai t-hitung semuanya lebih besar daripada nilai t-tabel pada derajad kepercayaan sebesar 5 persen, yaitu 2.056. Hasil ini memperlihatkan bahwa selisih anggaran 
dengan realisasi anggaran belanja langsung pada pemerintah daerah provinsi DKI berbeda secara signifikan untuk setiap enam bulanannya.

Tabel 6 menyajikan ringkasan hasil uji beda rerata lintas semester atas belanja tidak langsung yang dihitung untuk setiap tahunnya. Nilai t-hitung semuanya jauh lebih besar daripada nilai t-tabel pada derajad kepercayaan sebesar 5 persen, yaitu 1.96. Hasil ini memperlihatkan bahwa selisih anggaran dengan realisasi anggaran belanja tidak langsung pada pemerintah daerah provinsi DKI dengan definisinya masing-masing juga berbeda untuk setiap semesternya.

Tabel 6

Ringkasan Hasil Uji Beda Rerata Lintas Semester Variansi Belanja Tidak Langsung Pemerintah Daerah DKI Jakarta

\begin{tabular}{cccccc}
\hline Variansi & Nilai & \multicolumn{4}{c}{ Tahun } \\
\cline { 3 - 6 } Anggaran & Uji & 2004 & 2005 & 2006 & 2007 \\
\hline Definisi A & t-hitung & 38.4128 & 9.9302 & 33.8744 & 13.9028 \\
Definisi B & t-hitung & 40.6857 & 46.3426 & 34.9555 & 13.7004 \\
\hline
\end{tabular}

Nilai t-tabel $(5 \% ; 148)=2.264$ (satu sisi)

Sumber: Pemda Provinsi DKI Jakarta (diolah)

Hasil tersebut mengungkapkan tingkat realisasi anggaran untuk kedua kategori belanja memang tidak sama untuk semester pertama dan semester kedua. Realisasi anggaran cenderung lebih melampaui target pada paruh kedua pada masing-masing tahun. Kemungkinan penjelasan yang dapat diajukan sebagai penyebab adalah kurangnya keterpaduan antara perencanaan dengan penganggaran dalam rerangka waktu (time frame) yang panjang. Konsekuensinya, relevansi program/kegiatan menjadi kurang responsif dengan permasalahan yang dihadapi serta kurang relevan dengan peluang yang ada. Kesemuanya ini menjadikan konsistensi dan sinkronisasi program masih relatif lemah, baik secara vertikal maupun horizontal.

\section{Variansi Antarpos Anggaran}

Tabel 7 dan Tabel 8 menyajikan masing-masing ringkasan hasil uji Anova dua jalur lintas 14 pos anggaran belanja langsung dan 75 pos belanja tidak langsung selama delapan semester. Nilai F-hitung pada umumnya lebih besar daripada nilai F-tabel pada derajad kepercayaan sebesar 5 persen, yaitu 2.027 dan 1.313. Hasil ini memperlihatkan bahwa selisih anggaran dengan realisasi anggaran pada pemerintah daerah provinsi DKI dengan definisinya masingmasing berbeda untuk setiap unit SPKD.

Perkecualian terjadi pada anova atas belanja tidak langsung lintas pos anggaran dengan definisi B. Jika pengujian dilakukan pada risiko sebesar 1 persen, nilai F-hitung lebih kecil daripada nilai kritis F-tabel sebesar 2.674. Ketiadaan perbedaan senjangan anggaran antarpos anggaran ini dapat dimaklumi terkait dengan definisi selisih anggarannya. Selain itu, pos-pos pada belanja tidak langsung pada umumnya bersifat berulang dan selalu ada tiap tahun. Oleh karenanya, penganggarannya menjadi lebih mudah dan selisihnya juga menjadi semakin kecil. 
Tabel 7

Ringkasan Hasil Anova Dua Jalur Lintas Semester \& Pos Anggaran Variansi Belanja Langsung Pemerintah Daerah DKI Jakarta, 2004-2007

\begin{tabular}{cccl}
\hline \multirow{2}{*}{ Variansi Anggaran } & \multicolumn{2}{c}{ Nilai ANOVA } & \multicolumn{1}{c}{ Simpulan } \\
\cline { 2 - 3 } Definisi A & F-hitung (1) & F-hitung (2) & \\
\hline Definisi B & 45.2730 & 9.0900 & $\begin{array}{l}\text { ada perbedaan selisih anggaran } \\
\text { antarsemester di tiap tahun dan } \\
\text { antarpos anggaran } \\
\text { ada perbedaan selisih anggaran } \\
\text { antarsemester di tiap tahun dan } \\
\text { antarpos anggaran }\end{array}$ \\
\hline
\end{tabular}

Tabel 8

Ringkasan Hasil Anova Dua Jalur Lintas Semester \& Pos Anggaran Variansi Belanja Tidak Langsung Pemerintah Daerah DKI Jakarta, 2004-2007

\begin{tabular}{cccl}
\hline \multirow{2}{*}{ Variansi Anggaran } & \multicolumn{2}{c}{ Nilai ANOVA } & \multicolumn{1}{c}{ Simpulan } \\
\cline { 2 - 3 } Definisi A & F-hitung (1) & F-hitung (2) & \\
\cline { 1 - 2 } Definisi B & 154.9875 & 3.0717 & $\begin{array}{l}\text { ada perbedaan selisih anggaran } \\
\text { antarsemester di tiap tahun dan } \\
\text { antarpos anggaran } \\
\text { ada perbedaan selisih anggaran } \\
\text { antarsemester di tiap tahun } \\
\text { tidak ada perbedaan selisih anggaran } \\
\text { antarpos anggaran }\end{array}$ \\
\hline
\end{tabular}

Nilai F-tabel $(5 \% ; 7 ; 518)=2.027$

Nilai F-tabel $(5 \% ; 74 ; 518)=1.313$

Sumber: Pemda Provinsi DKI Jakarta (diolah)

Hasil statistik di atas mengindikasikan bahwa tiap SPKD pada tiap semester bervariasi dalam menetapkan anggaran belanja yang hendak dicapai sebagai sasarannya masing-masing. Beberapa aspek bisa diajukan sebagai faktor pendorongnya adalah program/kegiatan saling tumpang tindih antar SKPD dan bahkan saling meniadakan. Pengamatan di lapangan menunjukkan pertanggungjawaban kinerja kegiatan masih tetap cenderung fokus pada pelaporan penggunaan dana. Hal demikian dapat terjadi paling tidak, sebelum PP 8/2006 ditetapkan, keterpaduan Laporan Keuangan dengan Laporan Kinerja masih belum jelas.

Dalam konteks pelaporannya itu sendiri, spesifikasi indikator kinerja dan target kinerja masih relatif lemah. Bahkan pada beberapa kasus, penetapan besar belanja tidak didasarkan pada target kinerja keluaran (output) atau hasil (outcome). Cara penetapan semacam ini mengakibatkan volume output berubah, tetapi total belanja tidak berubah. Dalam konteks pembagian fungsi dan kegiatannya, indikator kinerja untuk Belanja Administrasi Umum (dulu disebut Belanja Rutin) dan Belanja Operasional dan Pemeliharaan (dulu disebut Belanja Pembangunan) masih tetap belum jelas. Hal ini secara nyata ditunjukkan dengan adanya Belanja Pegawai (honor) pada tiap kegiatan. Secara keseluruhan, kelemahan manajemen keuangan pemerintah daerah pada umumnya dibuktikan dengan fakta bahwa penetapan APBD seringkali terlambat dan perubahan APBD seringkali di akhir tahun anggaran. 


\section{Simpulan}

Makalah ini mengamati selisih anggaran belanja yang terjadi pada pemerintah daerah provinsi DKI Jakarta selama periode 2004-2007. Basis teori yang digunakan sebagai pijakan adalah teori keagenan dan teori komparatif. Berdasarkan uji beda rerata dan anova dua jalur lintas semester dan lintas pos anggaran terhadap belanja langsung dan belanja tidak langsung, simpulan yang dapat diperoleh adalah terjadi perbedaan selisih anggaran belanja yang secara statistik signifikan.

Bukti di atas menunjukkan ketidakberlakuan teori komparatif. Sudah menjadi pengetahuan umum, pemerintah daerah yang secara finansial miskin cenderung selalu menganggarkan penerimaan lebih tinggi dan menetapkan anggaran belanja lebih rendah dari tingkat "kewajaran". Paper ini menyajikan fakta empirik bahwa -- pada sisi pengeluaran -- daerah yang secara finansial kaya (seperti DKI Jakarta) ternyata juga cenderung menganggarkan belanja secara (relatif) lebih rendah dari kemampuan sedemikian rupa sehingga perbedaan anggaran dengan realisasi belanjanya jauh berbeda.

Simpulan di atas memberi implikasi bahwa laporan resmi APBD kurang memuat kandungan informasi yang bermanfaat bagi pengambilan keputusan. Hal ini sangat beralasan mengingat ada perbedaan yang signifikan antara informasi anggaran dengan informasi realisasinya. Lebih lanjut, hal ini menunjukkan pula eksistensi fenomena asimetri informasi antara pihak-pihak yang berkepentingan, terutama birokrat pemerintah daerah dan masyarakat.

Sejalan dengan otonomi daerah dan desentralisasi fiskal yang terus berkembang di Indonesia, temuan atas kasus di DKI Jakarta ini dapat dijadikan contoh betapa lemahnya pengelolaan keuangan daerah. Beriringan dengan peningkatan kemandirian keuangan daerah, pemerintah daerah di Indonesia sepatutnya juga mengembangkan transparansi dan akuntabilitas operasi pemerintahannya. Satu indikator pentingnya adalah melalui laporan keuangan yang relevan, cepat, akurat, lengkap, dan dapat diuji kebenarannya sekaligus mencerminkan kinerjanya melalui keterpaduan sistem antara perencanaan, penganggaran, dan pelaksanaan serta pelaporannya. Sejalan dengan itu, keterlibatan partisipasi masyarakat dalam DPRD dalam sistem tersebut juga merupakan satu faktor penting yang tidak bisa dikesampingkan.

Paper ini masih sebatas pada kajian selisih anggaran pada aspek hasil (ex post) belum menyentuh pada penyebab terjadinya (ex ante). Studi lanjutan dengan topik yang sama masih terbuka dilakukan dengan memperhatikan beberapa faktor yang disebut terakhir. Sejauh tersedia, hasil pengamatan dengan spektrum data bulanan tentu akan lebih menjanjikan. Hal ini potensial ditempuh dengan memasukkan faktor likuiditas (cash flow) pemerintah daerah sebagai determinan selisih anggaran. Fakta yang sering terjadi realisasi anggaran belanja meleset akibat dana segar tidak tersedia pada saat yang tepat.

\section{Daftar Referensi}

Buchanan, J.M.. 1967. Public Finance in Democratic Process. University of North Carolina Press: Chapel Hill. 
Dougan, W.R. dan Kenyon, D.A.. 1988. Pressure Groups and Public Expenditures: The Flypaper Effect Reconsidered. Economic Inquiry. 26(1), Januari: 159-70.

Duncombe, W.D..1996. Public Expenditure Research: What Have We Learned?. Public Budgeting and Finance. 16(2): 26-58.

Falikhatun. 2007. Interaksi Informasi Asimetri, Budaya Organisasi, dan Group Cohesiveness Dalam Hubungan Antara Partisipasi Penganggaran dan Budgetary Slack (Studi Kasus Pada Rumah Sakit Umum Daerah Se-Jawa Tengah. Makalah Simposium Nasional Akuntansi X, Makassar. 25-27 Juli.

Gallagher, M.. 1999. An Analysis of Municipal Revenues, Transfers, Population, and Poverty in El Salvador. USAID/EI Salvador. Contract No. 519-C-00-00153-00, Task Order No. 15 , November 1999, http://www.devtechsys.com/publications/ municipos/mark6.pdf.

Goetz, C.J.. 1977. Fiscal Illusion in the State and Local Finance. dalam T.E. Borcherding, (Ed.), Budgets and Bureaucrats: the Sources of Government Growth. Duke University Press Durham: 176-87.

Gordon, L.A., dan F.E. Sellers. 1984. Accounting and Budgeting Sistem: The Issue of Congruency. Journal of Accounting and Public Policy. 3: 259-292.

Grossman, P.J.. 1989. Intergovernmental Grants and Grantor Government Own-Purpose Expenditures. National Tax Journal. 42(4), Desember: 487-94.

Grossman, P.J.. 1990. The Impact of Federal and State Grants on Local Government Spending: A Test of the Fiscal Illusion Hypothesis. Public Finance Quarterly. 18(3), Juli: 313-27.

Halim, A.. 2001. Anggaran Daerah dan Fiscal Stress, Sebuah Studi Kasus pada Anggaran Daerah Provinsi di Indonesia. Jurnal Ekonomi dan Bisnis Indonesia. 16 (4): 346-357.

Halim, A.. 2002. Analisis Varian Pendapatan Asli Daerah dalam Laporan Perhitungan Anggaran Pendapatan dan Belanja Daerah Kabupaten/Kota di Indonesia. Disertasi Doktor dalam IImu Ekonomi, UGM, Yogyakarta, tidak diterbitkan.

Heyndels, B. dan C. Smolders. 1994. Fiscal Illusion at the Local Level: Empirical Evidence for the Flemish Municipalities. Public Choice. 80(3/4), Desember: 325-38.

Holtz-Eakin, D.. 1992. Elections and Aggregation: Interpreting Econometric Analysis of Local Governments. Public Choice. 74(1), Februari: 17-42.

King, D.N.. 1984. Fiscal Tiers: The Economics of Multi-Level Government. George Allen and Unwin: London.

Kuncoro, H.. 2005. Pengaruh Transfer Antarpemerintah terhadap Kinerja Fiskal Pemerintah Daerah, Pertumbuhan Ekonomi, dan Disparitas Pendapatan Regional, Kota dan Kabupaten di Indonesia, 1988-2003. Disertasi Doktor dalam Ilmu Ekonomi pada Sekolah Pascasarjana UGM Yogyakarta, tidak diterbitkan.

Kuncoro, H.. 2007. Perilaku Asimetris Pemerintah Daerah Kota dan Kabupaten Atas Perubahan Besaran Transfer Dari Pemerintah Pusat. Makalah pada The ${ }^{7 t}$ Accounting Conference, FE UI, Depok. 7-9 November 2007.

Majidi, N.. 1997. Anggaran Pembangunan dan Ketimpangan Ekonomi Antardaerah. Prisma. 3 , Maret : 3-16.

Mardiasmo. 2005. Akuntansi Sektor Publk. Andi: Yogyakarta.

McGuire, M.C.. 1973. Notes on Grant-in-Aid and Economic Interactions among Governments. Canadian Journal of Economics. 6(2), Mei: 207-21.

Munawar. 2006. Pengaruh Karakteristik Tujuan Anggaran terhadap Perilaku, Sikap dan Kinerja Aparat Pemerintah Daerah di Kabupaten Kupang. Tesis, Universitas Brawijaya, Malang, tidak diterbitkan.

Naganathan, M. dan K.J. Sivagnanam. 1999. Federal Transfers and Tax Efforts of States in India. Indian Economic Journal. 47(4), April: 101-10.

Nazara, S.. 1997. Struktur Penerimaan Daerah Tingkat Provinsi di Indonesia. Prisma. 3: 17-26. 
Niskanen Jr., W.A.. 1968. The Peculiar Economics of Bureaucracy. American Economic Review. 58(2), Mei: 239-305.

Nurmanaf, A.R.. 1999. Kesenjangan Pengeluaran Pembangunan Antarwilayah dan Propinsi di Indonesia. Ekonomi dan Keuangan Indonesia. 47(4), Desember: 415-22.

Pommerehne, W.W. dan F. Schneider. 1978. Fiscal Illusion, Political Institutions, and Local Public Spending. Kyklos. 31(3): 381-408.

Rahayu, S., U. Ludigdo, dan D. Affandy. 2007. Studi Fenomenologis terhadap Proses Penyusunan Anggaran Daerah Bukti Empiris Dari Satu Satuan Kerja Perangkat Daerah di Provinsi Jambi. Makalah Simposium Nasional Akuntansi X, Makassar. 25-27 Juli.

Romer, T. dan H. Rosenthal. 1979a. Bureaucrats versus Voters: On the Political Resource Allocation by Direct Economy of Democracy. Quarterly Journal of Economics. 93(4), November: 563-87.

Romer, T. dan H. Rosenthal. 1979b. The Elusive Median Voter. Journal of Public Economics. 12(3), Oktober: 143-70.

Romer, T. dan H. Rosenthal. 1980. An Institutional Theory of the Effect of Inter-governmental Grants. National Tax Journal. 33(4), Desember: 451-58.

Stiglitz, J.E.. 1988. Economics of the Public Sector. $2^{\text {nd }}$ Edition. W.W. Norton and Co. Inc., New York.

Schawallie, D.P.. 1989. The Impact of Intergovernmental Grants on the Aggregate Public Sector. Quarum Books Greenwood Press: New York.

Slack, E.N. dan R.M. Bird. 1983. Local Response to Intergovernmental Fiscal Transfers: The Case of Columbia. Public Finance. 38(3): 429-39.

Suryani, S.. 2004. Penyusunan Anggaran Partisipatif Berbasis Kinerja dalam Mendukung Kesejahteraan Masyarakat Ditinjau dari Nilai-Nilai Budaya Sumba Timur. Tesis-S2, Universitas Brawijaya. Tidak diterbitkan.

Turnbull, G.K.. 1993. Fiscal Illusion and the Output Expansion Hypothesis. Public Finance Quarterly. 21(3), Juli: 305-21.

Vasquez, M.J.. 1983. Renters' Illusion or Savvy?. Public Finance Quarterly. 11: 237-43.

Wuryanto, L.E.. 1996. Fiscal Decentralization and Economic Performance in Indonesia: An Interregional Computable General Equilibrium Approach. Unpublished Ph.D. Dissertation. Faculty of Graduate School of Cornell University.

\footnotetext{
- Haryo Kuncoro adalah staf peneliti di FE UNJ Jakarta dan pengajar pada beberapa PTS di Jakarta. Beliau memperoleh gelar Sarjana Ekonomi (1993), Magister Sains (1999), dan Doktor dalam Ilmu Ekonomi (2005), kesemuanya dari Universitas Gadjah Mada Yogyakarta. Karya-karya ilmiahnya telah banyak diseminarkan dan dipublikasikan di berbagai jurnal di tanah air. Pada tahun 1999, 2001, dan 2004, penulis terpilih menjadi finalis Pemilihan Peneliti Muda Indonesia yang diselenggarakan oleh LIPI. Bidang riset yang ditekuninya adalah Ekonomi Regional dan Ekonomi Publik. HP: 0817267325 , haryo_kuncoro@hotmail.com
} 